\title{
Precarious Learning and Labour in Financialized Times
}

\author{
Jamie Magnusson \\ University of Toronto
}

\begin{abstract}
Our current globalized economic regimes of financialized capital have systematically altered relations of learning and labour through the dynamics of precarity, debt, and the political economy of new wars. The risks of these regimes are absorbed unevenly across transnational landscapes, creating cartographies of violence and dispossession, particularly among youth, indigenous, working class, and racialized women. Presently there is surprisingly little discussion on the relevance of financialization for adult educators. Transnational resistances organizing against neoliberal restructuring, austerity policies, and debt crises are emerging at the same time that massive investments are being made into homeland security and the carceral state. This paper opens up discussion on the implications of financialized times for educators, and develops an analytic framework for examining how these global realities are best addressed at local sites of adult and higher education.
\end{abstract}

Key words: financialization, imperialism, neo-colonialism

Jamie Magnusson teaches in the Adult Education and Community Development Program in the Department of Leadership, Higher and Adult Education of the Ontario Institute for Studies in Education at the University of Toronto. Her teaching and scholarship explore the intersections of adult and higher education, neoliberal economic policy, and globalization. Working from a feminist Marxist perspective, her recent research documents how the financialized economy has been affecting women in their pursuit of higher education and their ability to negotiate economic, social, and cultural security.

E-mail: jamielynn.magnusson@utoronto.ca

Acknowledgement:

This paper springs from work presented at the University is Ours conference in Toronto (May, 2012) and papers presented at the Historical Materialism conference in Toronto (May, 2012) and London (November, 2012). I would like to acknowledge my colleagues within the Marxist Feminist Reading Group lead by Shahrzad Mojab at OISE, University of Toronto. Their collegiality and sharing has contributed enormously to my work on the topic of financialization.

Brock Education Volume 22, No. 2, Spring 2013, pp. 69-83 


\section{Precarious Learning and Labour in Financialized Times}

The financialization of capital goes hand in hand with the topic of neoliberal economics, and yet has received comparatively little attention. The literature on adult and higher education reflects this trend in that there is by now quite a large literature documenting the consequences of neoliberal economic policy on higher education (e.g., Slaughter \& Rhoades, 2004; Currie \& Newson, 1998). However, there is relatively little literature examining how the financialization of capital has been a significant dynamic shaping adult and higher education. This paper develops some organizing frameworks through which we can better understand the implications of financialization for adult and higher education in terms of its gendered and racialized transnational materialities. The most critical organizing frame introduced in the paper is that which connects financialization to the literature on monopoly finance capital, and the implications for understanding the material underpinnings of 'the new imperialism' (Harvey, 2003).

Financialization can be broadly defined as the increasing importance of financial markets in the sum total of international economic activity (Dore, 2000). It can also be understood in terms of the importance of the stock market with regard to capital accumulation. Accumulation in stock market terms entails beating a game of averages, and in the late twentieth century, particularly after the dissolution of the direct convertibility of the U.S. dollar to gold, being ahead in the game depends less on how many units are sold; rather it resembles a bet on who's things are going to sell relatively faster, or, a bet on future earnings (Bichler \& Nitzan, 2004). Everything is up for financial speculation within the so-called FIRE economy (Finance, Insurance, Real Estate), including social crises, wars, debt, and even natural disaster (Klein, 2007). Described as a systematic transformation of mature capitalist economies (Lapavitsas, 2011), financialization is sometimes discussed as a recent phenomenon. However, given that Lenin provided a detailed analysis of financialization as a critical dimension of monopoly capital in his famous treatise on imperialism, it is more appropriate to understand financialization as an historical process and not a brand new phenomenon. This paper takes the position outlined by Bellamy Foster (e.g., 2007; 2010) that the financialized form of capital is not a new stage in capitalism in that the basic problem of accumulation within production remains the same. However, financialization is an emergent form of the monopoly stage, and in this sense the term 'monopoly finance capital' is appropriate.

Linking financialization to monopoly capital is critical to the analysis provided in this paper in that monopolization is the historical process crucial to understanding the globalized organization of neocolonialism as imperialism (Nkrumah, 1965). Although it may appear on the surface that the form of monopoly finance capital of Lenin's day differs in certain ways (to be described later) from its present-day form, the social relations of imperialism organized through production and monopolization remain very much the same. I therefore use imperialism as a key concept to understand the social relations of power organized through monopoly finance capital, and in particular transnational relations organizing gender, race, and neocolonialism (Mojab, 2011). I follow the analysis through to examine the implications for adult education in an era of international relations of global finance capital.

The paper is organized into the following three sections. First I will provide an outline of financialization as experienced at the level of the everyday. I will then summarize financialization as an economic process organizing relations of imperialism through the 
concentration of capital accumulation into fewer and fewer hands. Finally, I discuss the implications of financialization for adult and higher education in an era of globalization.

\section{Understanding Finance Capital at the Level of the Everyday}

To put it bluntly, youth around the world are angry. The world is witnessing an unprecented rise of youth and student revolts in regions as diverse as: California, Egypt, United Kingdom, Chile, Quebec, Wisconsin, Italy, Jamaica, North Africa. Spain, Russia, South Africa, Barbados, Colombia, New Delhi, China, Iceland, Greece, Ireland, Toronto, and Indigenous youth from Bolivia to Oka. Movements such as the Jasmine Revolution, Quebec Riots, Pussy Riot, Arab Spring, Occupy Wall Street, and Idle No More are all illustrative of this growing trend of disenchanted youth actively voicing their discontent with the current global economic situation and the compulsion of lowered expectations.

In the years preceding the global economic crash of 2008 tensions had been building. Manufacturing infrastructure (e.g., fixed capital) had been eroding leading to factory closures, lay-offs, and off-shored production (Harvey, 2010; Marazzi, 2010). As the unionized manufacturing sector declined, wage repression and worker discipline intensified (Panitch, Albo $\&$ Chibber, 2012). Free zones have been emerging everywhere from Jamaica to Winnipeg, Manitoba (http://www.foreigntradezone.ca, accessed august 8, 2012). The environment has been degraded to a point where youth have unprecedented health problems ranging from asthma to autism (Goldin-Rosenberg, 2008); they face an uncertain future due to the known and unknown effects of exposure to radiation and toxins that leak into rivers, lakes, landfill, and industrialized bioengineered agricultural products. With subsistence living almost universally eradicated, the sale of labour has become necessary for the sustenance of life; however, the possibility of landing a full-time, Keynesian era job has, in colloquial terms, come to resemble a crapshoot. Instead, youth, racialised migrant workers, and particularly women, are increasingly working at a string of temporary, part-time jobs to make ends meet. This scenario is referred to as the intensification of precarity: precarious employment and precarious housing. Living on the edge of survival and disaster has become a globalized reality.

In Canada, attending college or university is no longer the semi-guaranteed pathway to economic security. As the Keynesian welfare state continues to undergo neoliberal restructuring, the state is systematically offloading the cost of higher education onto students (Magnusson, $2000 \mathrm{a} ; 2000 \mathrm{~b} ; 2005 \mathrm{a} ; 2005 \mathrm{~b} ; 2005 \mathrm{c} ; 2011$ ). Youth are handling the rising cost of higher education by taking on crushing debt loads (Canadian Federation of Students, http://cfs.bc.ca/section/48). In Canada, although some of the debt is acquired through public sources of credit in the form of government student loans, increasingly students are availing themselves of credit from predatory private-for-profit sources: credit card companies, for-profit publicly traded student loan corporations such as Sally Mae, multiyear cell phone and internet contracts, and a plethora of retail credit cards. If students manage to finish their degrees, they find themselves in debt servitude (Hedges \& Sacco, 2012), and their chances of securing full time employment have negligibly improved (Magnusson, 2011).

In addition, jurisdictions such as Ontario, through the Higher Education Quality Council (HECQO), are pushing for a "more differentiated" higher education system. This policy language is reflected in Premiere McGuinty's throne speech (2010) in which his government outlined a plan to shift the manufacturing intensive economy to a knowledge-based economy by increasing local postsecondary participation rates to $70 \%$, while at the same time pursuing the 
lucrative international student market. We know from HECQO position papers that increasing participation rates in higher education entails proposals such as creating an online provincial undergraduate system, hiring teaching-only professors, and accepting cash from anyone currently ineligible for traditional universities; in the meantime traditional universities are developing ever more layers of differentiation, with exclusive and gated sectors of the system serving an elite minority (Magnusson, 2011). At a time when over half of the traditional university undergraduate programs are already taught by precarious workers of the knowledge economy, this gesture can only be seen as one that will potentially intensify the production of tiers among knowledge workers: those paid to teach and those paid to do research. In a system within which the vast majority $(80 \%)$ of full professors within traditional universities are male and white, and over $50 \%$ of the precarious professors are women and racialized faculty, questions of equity regarding knowledge production and cultural representation have never been more critical, and at the same time more violently suppressed as evidenced in Quebec as well as in many international jurisdictions (Magnusson, 2011, statistics from the Canadian Association of University Teachers website, accessed 2011).

Within this environment, challenges to a state fiercely intent on pushing through austerity policies are met with state repression and violence. In Quebec, the passing of Bill 78 legitimized unprecedented state violence against student protestors, criminalizing scores of youth whose main 'crime' was to challenge the neoliberal trajectory of economic and education policy by staging a strike. In Russia, the Pussy Riot, a female punk band accused of storming a cathedral and beseeching 'the virgin Mary' to rid Russia of Vladimar Putin, were sentenced to jail. Students attending the Occupy Movement in California campuses were mercilessly pepper sprayed. In Chile police are using water canons and tear gas to disperse student protesters. In London and Montreal police 'kettled' (or corralled) student protestors, arresting hundreds. During the G20 Toronto police coralled hundreds of people, protestors and bystanders alike, and exercised arbitrary detainment. In Syria, protest is met with massacre. In Gauntanamo Bay, prisoners are detained, tortured, and their legal and human rights suspended. Superprison construction is on the rise in Canada, the U.S., and the U.K. These events illustrating the state's investment into technologies of securitization are also evidenced in terms of heightened surveillance.

For example, in addition to the criminalization of student and youth protestors, "Not in Education or Employment or Training" (NEET) lists, initiated in the UK have quickly spread to other jurisdictions, are being assembled, consisting of the names of 16 to 24 year old youths not in school (Colley, 2003). Youth designated as "NEETS" are of interest to 'authorities' because they are seen as more likely to commit crimes. The NEET lists serve to extend and intensify the surveillance and criminalization of precarious youth. Criminalization of the poor, of course, has a long history within capitalist societies, serving as a means to regulate a surplus army of workers when the labour market is unforgiving.

More current analyses emphasize the gendered and racialized organization of policing and incarceration. For example, Sudbury (2005) discusses the global explosion in women's imprisonment, but also the intensification of this phenomenon within the U.S. global epicenter. She writes:

Beginning in 1973, an explosion in the number of women in prisons and jails in the United States has contributed to one of the largest prison building booms in world history. Whereas in 1970 there were 5,600 incarcerated women, by June 2001, 161,200 women 
were held in U.S. prisons and jails, representing a staggering 2,800 percent increase. (pp. xiv)

She points out that the number of imprisoned males has likewise grown exponentially, with the total population of jails and prisons in the U.S. surpassing two million. However, she adds, while "women make up only $9 \%$ of those incarcerated nationally, the rate of population growth for incarcerated women outstrips that of men"(pp. xiv). While the intensity of these trends is felt most acutely in the U.S., Canada and the U.K. are following the same pattern. Prison growth in the global south, while less visible, Sudbury argues, is equally problematic, with increasing numbers of U.S. style megaprisons. She continues:

Statistics that look at gender but not race and class underrepresent the impact of the prison explosion on women of color and indigenous women. In all countries just mentioned, oppressed racialized groups are disproportionately targeted by the criminal justice system. The crises of women's prisons can therefore be read as a crisis for working class women and indigenous women worldwide. (pp. xiv)

Described by Carpenter (2012) as the dialectic of security and insecurity, the themes of precarity and debt on the one hand, and securitization on the other, are woven through the dynamics that I am referring to as the financialization of everyday life. Financialization, as I mentioned earlier, is a broad organizing set of economic relations, but the effects of these relations are experienced at the level of the everyday, and are reorganizing social relations of learning and labour, as hinted above. The picture emerging on the 'insecurity' side of the dialectical coin is one of precarious existence at the rugged edges of casualized work and unemployment, lack of affordable housing, erosion of social programs, community programs, and unprecedented exposure to a profileration of predatory speculative credit markets: money is to be made speculating on the 'future earnings' derived through production of insecurity and dispossession (Khosla, 2005; 2008). The picture emerging on the 'security' side of the coin is the intensification of technologies of social and political control through what could be thought of as full spectrum practices of imperialism: surveillance, prisons, riot control, and so on. These technologies and practices of imperialism are being innovated through the speculative dynamics of the market, and used as instruments of coercion to maintain an accumulation regime that thrives best on insecurity, social crises, war, and even disaster. Money is to be made speculating on the 'future earnings' of security.

The next section takes a closer look at financialization in order to better understand how it is that accumulation regimes speculating on precarity and debt are linked to accumulation regimes speculating on securitization. The final section of the paper then considers the implications in terms of Adult and Higher Education.

\section{Financialization and Transnational Relations of Imperialism}

David Olive (2012) reports in his article in the Toronto Star:

Most recently, Carney, stating the obvious, said Wednesday that Canada has no hope of achieving global competitiveness if Corporate Canada insists on continuing to sit on more 
than half a trillion dollars of idle cash rather than investing it in our country's future, 2012 ).

This report in a local paper reiterates the point repeatedly made by Harvey (e.g., 2003; 2010) that the era of financialization is not characterized by an absence or curtailing of 'surplus capital' but rather the opposite: too much surplus and not enough re-absorption or reinvestment. Using a version of an analysis commonly attributed to Rosa Luxemberg (1912), Harvey points out that the problem we currently face economically speaking is one of "how" to invest the surplus that is accumulating. Olive points out that Corporate Canada is sitting on more than a half a trillion dollars that is idle, and yet governments internationally are negotiating debt crises of epic proportions, instituting austerity measures that are breaking the backs of labour, and at the same time throwing money into homeland security, super jails, surveillance, and wars. How do we account for these contradictions? As Carpenter (2012) suggests, these contradictions relate dialectically, representing two sides of the same accumulation coin. In order to understand this dialectical relation, we need some basic understanding into the dynamics of financialization.

As mentioned earlier, financialization can be broadly defined as the increasing importance of financial markets in the sum total of international economic activity. In his reviews on the topic, Bellamy Foster $(2007 ; 2010)$ emphasizes that financialization does not represent a new stage of capitalism, citing that the basic problem of accumulation within production remains the same. Rather, he argues, financialization represents an emergent form of the monopoly stage, and therefore recommends the term 'monopoly finance capital'. A century ago, Lenin (1916) had analyzed the tendency of capital toward monopolization, and cited its importance as the economic basis for imperialism. Mojab (2011) argues that transnational imperialism then, and today, is dependent on strong nation states with developed militaries that are organized hierarchically: this is the so-termed "strong state thesis" of globalization. She states:

(S)ome theorists claim that imperialism is in the process of transforming into a new regime called 'Empire', characterized by eroding national borders and a dissolving nation-state system, which will leave the imperialist order without leaders or centers. This is an optimistic, 'post-imperialist' scenario in which sovereignty is deterritorialized, leaving room for increasing mobility of labor, fluidity of capital, ongoing migration, and organizing on an international level. In this context of the withering away of the nationstate, human beings are said to be able to realize the dream of building a world that will turn its back on pillage and piracy and move toward equality and justice. (pp. 170)

In contrast to the erosion of borders, we see massive investment into systems of homeland security, and a sustained commitment to fortify spheres of economic and political influence (Meiksins Wood, 2003). Mojab (2011) points out that borders within the European Union have dissolved to encourage free trade, but the EU has been closing its doors to economic migrants and refugees.

Lenin established that the formation of monopolies, and therefore relations of imperialism, is inherent to the capitalist system and is organized through the economic relations of financialization. Bellamy Foster $(2007 ; 2010)$ points out that through the post-war Keynesian period, the formation of multinational monopolies, or oligopolies, resulted in a concentration of profits for a minority of monopoly beneficiaries. As he describes, as capital becomes 
concentrated into fewer and fewer hands, the conditions that allowed for this accumulation to occur in the first place produces a barrier to re-investment. That is, concentration of capital into fewer hands eventually results in economic stagnation: consumption slows down, production slows down, and the overall effect is fewer profitable investment opportunities. In terms of the Olive article cited above, imagine how Corporate Canada may hesitate to reinvest the accumulation of corporate dollars into the auto-industry, or the manufacturing sector generally speaking. Southern Ontario's auto-sector is being completely re-organized: downsized and outsourced. It now does not make accumulation sense to reinvest in the productive capacity that produced the surplus in the first place: there would be diminishing returns. The result is even greater stagnation. In order to displace the effects of this stagnation, the now precarized workers require access to credit in order to keep consumption lively, and investors look to investing in the financial sector, rather than, say, the manufacturing sector.

Bellamy Foster suggests:

For the owners of capital the dilemma is what to do with the immense surplus at their disposal in the face of a dearth of investment opportunities. Their main solution from the 1970 's on was to expand their demand for financial products as a means of maintaining and expanding their money capital. On the supply side of this process, financial institutions stepped forward with a vast array of new financial instruments: futures, options, derivatives, hedge funds, etc. The result was skyrocketing financial speculation that has persisted now for decades. $(2007$, pp. 3)

Sweezy (1994) points out that over the history of capitalism, financial expansion was contemporaneous with growth in the productive sector. However, in late capitalism, financial expansion is occurring against a backdrop of decline in the productive sector (see also Harvey, 2010). That is, as Bellamy Foster (2007) suggests, financialization in late capitalism, rather than feeding on and contributing to economic health, is feeding off economic stagnation. Meiksins Wood (2003) argues that the global penetration and intensification of global finance monopoly is dependent on a hierarchically arranged system of nation states controlled through the U.S. epicenter (see also Harvey, 2003). She states:

The U.S. used its control of financial and commercial networks to postpone the day of reckoning for its own domestic capital, enabling it to shift the burden elsewhere, easing movements of excess capital to seek profits wherever they were to be found, in an orgy of financial speculation. (p. 133).

She argues that the U.S. develops trade rules (e.g., the structural adjustment policies, GATS, etc.), foreign aid, etc., to manipulate debt and financial speculation in ways that open subordinate economies for exploitation. Maintaining control over processes of intensified penetration requires what Meiksins Wood refers to as "surplus imperialism" that manifests in a state of permanent war. As she suggests, it is in the interest of the hegemon to not obliterate nation states, but to reinforce nation states at the same time as keeping challenges to imperialist supremacy in check. Neoliberal policies therefore become a necessary means of opening up subordinate economies, and to shift the burden of financialization internationally.

Bhattacharyya (2005) has argued that the globalized war economy refers to the opposite of the military industrial complex-'something like the war economy of the poor world'. Whereas 
financialization is historically associated with expansion in the productive sector (Sweezy, 1994), the new war economy creates wealth against a backdrop of precarity and economic stagnation (Melman, 2003). Rather than an enemy state, war is waged against the life of the population itself (Cooper, 2008). The new wars have been linked to the erosion of local infrastructures, to food crises, environmental catastrophes, social upheaval, and the continual threat of counterneoliberal rebellion (see also Cooper, 2008).

Education, through the implementation of neoliberal policies, enters into the speculative arena of finance capitalism, as does the war against the poor world, and the two become inseparable. In his ethnography of the Chicago urban school system, Means (2011) reveals how schools in the poor neighborhoods he taught in and came to study are the site of heightened surveillance practices within a political economy that has woven public education through emerging forms of prison industrialism and militarism. Saltman (2010) has documented how venture philanthropy is a significant vehicle through which the school systems in the same state are rearticulated as private enterprise, thereby encouraging education to enter into the economic relations of financialization. Reading across these two authors, we can see how education and the political economy of new wars become woven together through the relations of monopoly finance capitalism. Meiners and Quinn (2011) make the connection between permanent war economy, education, militarism, and prison:

The U.S. power structure has systemically starved civilian infrastructures that support our daily lives, from roads and public transportation and schools to libraries; it has abandoned communities to decay or private dollars. At the same time our prison and military infrastructures have grown, and are poised to fill the civilian void. With over 1.68 million men and women in military service, eleven hundred bases across the globe, and only six thousand foreign service officers and two thousand U.S. Agency for International Development (USAID) workers, the military is U.S. international aid, diplomacy, and foreign relations. There are more members in military bands than the State Department has foreign service officers. The armed forces are deployed for war and military intervention and for domestic and worldwide natural, political, and other disasters, including Hurricane Katrina, and Haiti's and Japan's earthquakes. Omnipresent and wellsupported, this is military normal. (p. 1)

The austerity policy environment encourages claw backs in public funding to education and community infrastructure at the same time that a surplus is accumulating. Meiners and Quinn (2011) outline the degree to these surplus monies are being invested into infrastructure for carceration and militarism:

Not unlike the permanent war economy that has reshaped our democratic institutions, the carceral landscape has remade possibilities for young people. Between 2000 and 2005, a new prison was built in the United States every twelve days. These massive investments in a carceral state, and the corresponding "tough on crime" criminal justice policies, created "million dollar blocks"-impoverished neighborhoods with so many residents in prison that the total cost of their incarceration exceeds $\$ 1$ million. Far from reducing big government, the shift from a welfare to a carceral and military state has translated into dramatic increases in the government's role in the lives of the poor. 
As these authors point out, for youth from neighborhoods that have been starved through 'austerity', choosing a well-funded military school over a school that lacks resources and feels like a prison is a rational choice. Similarly, for the economically elite, choosing a well-resourced gated university with corporate owned 5-star hotel-like student housing over an online undergraduate program taught by precarious knowledge workers, is a rational choice. At the same time, as examined by Carpenter (e.g., 2011) and Colley (e.g., 2011), opportunities for civic service and mentoring within communities have become streamlined through organizations such as Americorp and New Beginnings. These sites of adult education leave no room to leverage the kind of critical tools and engagement necessary to produce a citizenry that is able to work through and transform the social relations of global financial imperialism. As adult educators and scholars we need to reject sites of education that support financialized educational programs that manage rather than transform communities and affirm the fullest of human potentiality.

The global landscapes emerging under regimes of financial monopoly capitalism are bleak. These landscapes, however, emerge through contradictions and unpredictable opportunities to reinvent social and political spheres. Distinguished from a formal, uniform, systematic and inevitable process, the contradictions of capitalism manifested by the formal and the informal, the legal and the illegal, inter alia, offer opportunities for creative intervention by those of us committed to adult and higher education to organize praxes that offer literacy, engagement and invention appropriate to transforming precarious learning and labour in financialized times. The next section explores some of these opportunities.

\section{Tasks for Adult and Higher Education}

Not surprisingly, the advent of bleak times has given birth to revolutionary ethos and solidarity, and particularly among young people. I recently participated in conferences, teach-ins, and actions lead by part-time faculty and students: these sectors that comprise the majority of campus life are also absorbing the lion's share of the injurious consequences of financialized higher education. We are now seeing evidence of solidarity across these differently affected groups of knowledge workers, many in even the most privileged sectors are beginning to support actions aimed at countering what is increasingly understood as a systematic starvation and erosion of the democratic civic functions of colleges and universities. Constructing assemblies outside of university governance structures and connecting with communities, these activists are challenging the state and in the process transforming higher education and communities alike, as evidenced in Quebec. Students in Quebec are building solidarity across diverse sectors of workers, and supporters outside of Quebec wear their red patch of solidarity. On another front, Democracy Now reported that 300,000 students and public service workers rallied at the Wisconsin Statehouse in Madison to oppose the elimination of bargaining rights and the claw back of wages and pensions. Just when crowds might have expected attempts to exercise crowd control and blocked access, indicating contradictions in the ruling class, the police ceded control of the State Street doors. From the Arab Spring to Occupy, this past year has been one of challenging repressive economic regimes, and activists globally are learning from one another and teaching one another. At my own university, a General Assembly consisting of students and faculty began meeting outside formal governance structures, and hosting workshops and minicourses to learn about how neoliberal policy is impacting education. From these meetings, students connected across different institutions by hosting a conference entitled "The University is Ours". At the conference, students and faculty presented insightful analyses and creating 
analytic frameworks appropriate to the field of education in an era of precarious learning and labour. They also organized workshops around strategies of resistance and intervention, with constituents from different jurisdictions helping one another work through what needed to be done within local sites of resistance. Similar actions are taking place across campuses globally. These are fruitful sites of adult and higher education teaching and learning.

Mojab (2011) has argued that there is by now a large body of literature within adult education that engages with capitalism. As she points out, however, this literature typically does not engage with capitalism as imperialism and therefore cannot produce the analytic tools necessary to properly address the complexities of financial monopoly capitalism as a historical process. I myself have been guilty of my share of writing articles examining commodification of higher education as if the process of deepening market relations through neoliberal restructuring has somehow been separate from the political economy of the new wars. One might ask: Why this division? What are the social relations through which my critical gaze on commodification and market relations comes to be alienated from war realities?

In a recent article examining the policy discourse of "innovation" that has drenched our academic landscapes of colleges and universities, I point out how Canada's Innovation Strategy:, released just after 9-11, articulates innovation with biosurveillance within a political economy of new wars (Magnusson, 2012). The policy (Government of Canada, 2012) reads:

For the first time in 25 years, Canada is in the midst of a slowdown that is happening concurrently in every major market in the world. More than 40 percent of Canada's economic activity is generated by exports, and these have been hit hard by the global slowdown. This was reflected in our weaker performance in the first half of 2001. The events of September 11 further affected our performance, particularly in sectors such as transportation and tourism. In this period of uncertainty it is important to restore a sense of personal security, and that was a key goal of the Government of Canada's 2001 budget.(p. 12)

The policy goes on to articulate innovation in the area of surveillance as both an economic strategy and a state necessity. For instance, improved security measures at airports, including facial recognition systems, iris scans, and automatic thumb printing are examples of the kinds of technological innovations cited in the policy

College and university environments are saturated by and in the discourses of 'innovation' and 'knowledge economy'. The policy language of 'innovation' is now institutionalized in terms of ministry, biomedical, and campus offices of innovation. Many universities now have white papers aimed at reshaping institutions vis-a-vis the needs of a 'knowledge economy'. Analyses are emerging revealing the market relations shaping the policy discourses that articulate 'knowledge economics' and 'innovation' with neoliberal economic strategies. We need, however, to enrich our analyses to reveal the accumulation regimes' undergirding of precarious learning and labour within a context of the political economy of new wars. As a faculty member situated within a Canadian research-intensive university, and having emerged from the working class at the tail end of the Keynesian era, I have felt the tectonic shift produced through the Nixon shock and its afterwaves of financialization. Thus, until the realities of the political economy of permanent war enter into our collective experiential sphere, the predominantly white intelligentsia occupying full-time tenure trak positions within universities may not orient their publicly paid for knowledge work to these problems. Only when the imperialist relations of 
financialized capital have deepened so significantly that the damage and destruction felt by the rest of the world has finally entered into the gated communities of (privileged) academia will it be possible to engage the organized solidarity of these 'innovators' working for the 'knowledge economy'.

\section{Conclusion and Recommendations}

In the meantime, there are countless sites of engagement for adult and higher education workers who are "getting it". We need to be there at those sites, learning, leading, and transforming the financialized trauma that is hitting our communities hard. We can begin by educating ourselves on the topic of finanicialization and developing counter imperialist curriculum and pedagogies. We can develop sites of higher education that are deeply engaged with sites of adult education and community development. We can demand that the financial wealth accumulating through our centres and hubs of innovation be taxed so that at least half of the revenues are invested in infrastructure that serve public interests.

With regard to the last point, consider the Kitchener-Waterloo area wherein Waterloo has become the international, speculative hub of innovation, and Kitchener has become the object of neoliberal austerity as the manufacturing sector is starved into decline. Kitchener-Waterloo is a textbook example of a local geography of financialized higher education in relation to the community within which innovation hubs are constructed. Newson (Newson, Polster, \& Woodhouse, 2012) has recently argued that rather than viewing our universities as endangered, we may need to understand better their role as endangering the communities within which they are situated. The wealth produced through Waterloo innovation can and should be reinvested in democratically designed community infrastructure rather than expansion of a militarized carceral state.

Adult educators are uniquely positioned to address the creep of bleak times through public pedagogy and engagement. We can advocate for state regulated systems of loans that benefit rather than hurt debtors in their pursuit of education and training and economic success. We can advocate for tax reforms to ensure some of the wealth produced through hubs of innovation are reinvested back into communities hosting these centres. Our faculties of education can develop curricula that nurture and develop our communities, rather than curricula that support a global vision of knowledge economics that is productive of economic stagnation and social crises at the level of the local. The amount of work ahead of us is matched by the ingenuity and political will of youth connected through global cartographies of struggle, and who are already leading the way. 


\section{References}

Bhattacharyya, G. (2005). Traffick: The illicit movement of people and things. London, U.K.: Pluto.

Bellamy Foster, J. (2007, April). The financialization of capitalism. Monthly Review, 58(11). Retrieved from http://monthlyreview.org/2007/04/01/the-financialization-of-capitalism

Bellamy Foster, J. (2010, October). The financialization of accumulation. Monthly Review, 62(5). Retrieved from http://monthlyreview.org/2010/10/01/the-financialization-ofaccumulation

Bichler, S., \& Nitzan, J. (2004). Dominant capital and the new wars. Journal of World Systems Research, 10(2), 255-327.

Carpenter, S. (2011). Explaining the social relations of learning citizenship: Citizenship and ideology in adult education. In S. Carpenter \& S. Mojab (Eds.), Educating from Marx: Race, gender, and learning (pp. 63-86). New York, NY: Palgrave.

Carpenter, S. (2012). Children of war? Security, civic education, and democratic learning. Paper presented at the annual meetings of the American Education Research Association, Vancouver, BC.

Colley, H. (2011). Learning to mentor young people: A saintly vocation or an alienating experience? In S. Carpenter \& S. Mojab (Eds.), Educating from Marx: Race, gender, and learning (pp. 87-112). New York, NY: Palgrave.

Colley, H. (2003). Engagement mentoring for disaffected youth: A new model of mentoring for social inclusion. British Education Research Journal, 29(4), 521-542.

Cooper, M. (2008). Life as surplus: Biotechnology and capitalism in the neoliberal era. Seattle, OR: University of Washington Press.

Currie, J., \& Newson, J. (1998). Universities and globalization: Critical perspectives. Thousand Oaks, CA: Sage Publications.

Dore, R. (2000). Stock market capitalism: Welfare capitalism: Japan and Germany versus the Anglo Saxons. New York, NY and Oxford, U.K.: Oxford University Press.

Feldman, S., Geisler, C., \& Menon, G. A. (2011). Accumulating insecurity: Violence and dispossession in the making of everyday life. Athens, GA: University of Georgia Press.

Goldin-Rosenberg, D. (Producer), Mehernaz, L. (Producer), Lee, A. (Producer), \& 
Cohen, B. (Director). (2008). Toxic trespass: How safe are your children? [Motion picture]. Toronto, Canada: The National Film Board of Canada.

Government of Canada (2002). Canada's innovation strategy: New ideas, new opportunities. (Catalogue Publication No. Iu4-5/2002). Ottawa, ON: Innovation Secreteriat. Retrieved from http://publications.gc.ca/collections/Collection/Iu4-52002E.pdf

Harvey, D. (2003). The new imperialism. Oxford and New York, NY: Oxford University Press.

Harvey, D. (2010). The enigma of capital and the crises of capitalism. New York, NY: Oxford University Press.

Hedges, C., \& Sacco, J. (2012). Days of destruction, days of revolt. New York, NY: Nation Books.

Klein, N. (2008). The shock doctrine: The rise of disaster capitalism. Toronto, ON: Vintage Canada.

Khosla, P. (2004). Making low income women of colour count in Toronto. Canadian Dimension, 38(6), 42.

Khosla, P. (2005). Rethinking Marx's “primitive” accumulation as a materialist corporeal logic of everyday gendered, racialized and sexualized violence. (Unpublished masters research project). York University, Toronto.

Lapavitsas, C. (2011). Theorizing financialization. Work, employment and society, 25(4), 611-626.

Lenin, V. (1902). What is to be done? In Selected Works, Volume 1. Retrieved from http://www.marxists.org/archive/lenin/works/1901/witbd/

Lenin, V. (1963). Imperialism, the highest stage of capitalism. In Selected Works, Volume 1. Retrieved from http://www.marxists.org/archive/lenin/works/1916/imp-hsc/

Luxemburg, R. (1912). The accumulation of capital. (A. Schwarzschild, Trans., 1951). London and New York: Routledge.

Magnusson, J. (2000). Examining higher education and citizenship in a global context of neoliberal restructuring. Canadian Ethnic Studies, 32, 72-88.

Magnusson, J. (2000). Canadian higher education and citizenship in the context of state restructuring and globalization. Encounters on Education, 1, 107-123. 
Magnusson, J. (2005). Universities, corporations, and biotechnologies: New colonialisms of the $21^{\text {st }}$ century. International Journal of Applied Semiotics, 4(2), 35-48.

Magnusson, J. (2005). Information technology and higher education: Plugging Ontario into the knowledge society. Encounters on Education, 6, 119-135.

Magnusson, J. (2011). Degrees of alienation: This paper is definitely not a HECQO funded policy report. The College Quarterly, 14(4). Retrieved from http://www.collegequarterly.ca/2011-vol14-num04-fall/magnusson.html

Magnusson, J. (2012). Financialization and the gendered and racialized social organization of learning and labour. Paper presented at the Historical Materialism Conference, Toronto, Ontario.

Magnusson, J. (in press). Biosurveillance as a terrain of innovation in an era of monopoly finance capital. Policy Futures in Education.

Magnusson, J., \& Bischoping, K. (2005). Recalling the body in academic labour. Socialist Studies Bulletin, 76, 6-17.

Marazzi, C. (2010). The violence of financial capitalism. (K. Lebedeva, Trans., original work published 2010). Los Angeles, CA: Semiotext(3).

Means, A. (2012). Schooling in the age of austerity: Scenes from an urban public school. (Unpublished doctoral thesis). OISE, University of Toronto, Toronto.

Meiksins Wood, E. (2003). Empire of Capital. London, U.K.: Verso.

Meiners, E. R., \& Quinn, T. (2011, July/August). Militarism and education normal. Monthly Review, 63(3). Retrieved from http://monthlyreview.org/2011/07/01/militarism-andeducation-normal

Melman, S. (2003, March 15). In the grip of a permanent war economy. Counter Punch. Retrieved from http://www.counterpunch.org/2003/03/15/in-the-grip-of-apermanent-war-economy/

McGuinty, D. (2010, March). Speech from the throne. Speech presented at Queen's Park, Toronto, ON. Retrieved from http://www.ontla.on.ca/web/houseproceedings/house_detail.do?Date $=2010-03-08 \&$ Parl $=39 \&$ Sess $=2 \&$ locale $=$ en\#P50_2638

Mojab, S. (2011). Adult education in/and imperialism. In S. Carpenter \& S. Mojab (Eds.), Educating from Marx: Race, gender, and learning (pp. 167-190). New York, NY: Palgrave.

Newson, J., Polster, C., \& Woodhouse, H. (2012). Toward an alternative future for 
Canada's corporatized universities. English Studies in Canada, 38(1), 51-70.

Nkrumah, K. (1965). Neocolonialism: The last stage of imperialism. London, U.K.: Panaf.

Olive, D. (2012, August 24). Corporate billions could boost productivity. The Star. Retrieved from http://www.thestar.com/business/article/1246859--olivecorporate-billions-could-boost-productivity

Panitch, L., Albo, G., \& Chibber, V. (2012). Socialist register 2012: The crisis and the left. Pontypool, Wales: The Merlin Press.

Saltman, K. (2010). From Carnegie to Gates: The Bill and Melinda Gates Foundation and the venture philanthropy agenda for public education. In P. E. Kovacs (Ed.), The Gates foundation and the future of U.S. public schools (pp. 1-20). New York, NY and London, UK: Routledge.

Slaughter, S., \& Rhodes, G. (2004). Academic capitalism and the new economy: Markets, state, and higher education. Baltimore, MD: Johns Hopkins University Press.

Sudbury, J. (2005). Global lockdown: Race, gender, and the prison-industrial complex. New York, NY and London, U.K.: Routledge.

Sweezy, P. (1994). The triumph of financial capital. Monthly Review, 46(2), http://monthlyreview.org/1994/06/01/the-triumph-of-financial-capital 